Ëriks Trel̦s, Dr. iur.

Valsts policijas koledža, Latvija

\title{
TERORISMA ATTAISNOŠANA, TERORISMA SLAVINĀŠANA UN AICINĀJUMS UZ TERORISMU
}

\section{ACQUITTAL OF TERRORISM, GLORIFICATION OF TERRORISM AND INVITATION TO TERRORISM}

\begin{abstract}
Summary
On 26 April 2018, amendments were made to the Republic of Latvia Criminal Law, improving the regulatory framework regarding the terrorist offenses and related crimes, including acquittal of terrorism, invitation to terrorism and terrorism threats. The current article aims to initiate a debate on potential problems related to the application of the Section $79^{6}$ of the Criminal Law. The author offers his vision of the new regulatory framework application problems.
\end{abstract}

Atslēgvārdi: Terorisma attaisnošana, terorisma slavināšana, aicinājums uz terorismu, Krimināllikuma $79 .{ }^{6}$ pants

Keywords: glorification of terrorism, acquittal of terrorism, invitation to terrorism, the Criminal Law Section $79^{6}$

\section{Ievads}

2018. gada 23. maijā stājās spēkā grozījumi Krimināllikumā (turpmāk arī - KL), kas papildināja normatīvo regulējumu ar jaunu $\mathrm{IX}^{1}$ nodaļu "Noziegumi, kas saistīti ar terorismu”. ' Nodaḷā iekl̦autais 79. ${ }^{1}$ pants definē jēdzienu "terorisms". Savukārt 79. ${ }^{6}$ pantā "Terorisma attaisnošana, aicinājums uz terorismu un terorisma draudi" ir paredzēta atbildība par terorisma publisku slavināšanu vai attaisnošanu vai par publisku aicinājumu uz terorismu, vai par terorismu slavinoša, attaisnojoša vai uz terorismu aicinoša satura materiāla izplatǐšanu, kā arī par draudiem īstenot terorismu, ja ir pamats uzskatīt, ka tas var tikt veikts. N̦emot vērā darba apjoma ierobežojumu, jautājums par terorisma draudiem šajā rakstā netiks pētīts.

Analizējot Valsts drošības dienesta (turpmāk - VDD) darbības prioritātes 2019. gadā, šīs iestādes priekšnieks Normunds Mežviets atzina, ka "2019. gadā VDD sadarbībā ar nacionālajiem un ārvalstu partnerdienestiem galveno uzmanību veltīs Krievijas naidīgo aktivitāšu un terorisma draudu savlaicīgai identificēšanai un neitralizēšanai” ${ }^{2}$.

Publiskā pārskatā par Valsts drošības dienesta darbību 2018. gadā tika uzsvērts, ka "VDD vērtējumā islāmistu teroristu veidoto propagandas materiālu pieejamība

Grozījumi Krimināllikumā: LV likums. Pieņemts 26.04.2018.

2 Publiskais pārskats par Valsts drošìbas dienesta darbību 2018. gadā. Rīga: Valsts drošìbas dienests, 2018, 5. lpp. 
internetā palielina personu radikalizēšanās riskus. Internets (sociālie tīkli, mobilās saziṇas aplikācijas un slēgtie diskusiju forumi) teroristu grupējumiem joprojām ir nozīmīgākā platforma, kur tie izplata savus propagandas materiālus." ${ }^{3}$ Pārskatā tika uzsvērta preventīvo pasākumu nepieciešamība, "lai atbilstoši riska analīzei un spēkā esošajam terorisma draudu līmenim nodrošinātu efektīvas nacionālās pretterorisma sistēmas un tās elementu darbību" ", kā arī izceltas nozīmīgākās aktivitātes šajā jomā: 1) Latvijas pretterorisma sistēmā iesaistīto institūciju sadarbības un koordinācijas mehānismu pilnveidošana un reaǵěšanas spēju pārbaude; 2) terorisma riska objektu apsekošana, rekomendāciju izstrāde fiziskās drošỉbas uzlabošanai, kā arī līdzdalība publisku pasākumu fiziskās drošības plānošanā un īstenošanā; 3) radikalizācijas tendenču ierobežošanas koordinēšana; 4) ziņošanai par sprāgstvielu prekursoriem paredzētā kontaktpunkta darbības nodrošināšana; 5) gaisa kug̣u pasažieru datu reǵistra attīstība.

Raksta mērḳis ir sākt diskusiju par iespējamiem problēmjautājumiem, kas varētu rasties kriminālprocesu par terorisma attaisnošanu, terorisma slavināšanu un aicinājumu uz terorismu izmeklēšanas ietvaros, kā arī piedāvāt šo problēmu iespējamus risinājumus. Darbā izmantotas vispārīgas pētniecības metodes, piemēram, salīdzināšana un apkopojums, cēloņsakarību atklāšana, analīze un sintēze, kā arī tiesību normu interpretācijas metodes: gramatiskā, sistēmiskā, vēsturiskā un teleologiskā.

\section{Normativā regulējuma vēsturiskā attīstība}

2005. gada 16. maijā Eiropas Padome pieñēma Konvenciju par terorisma novēršanu (turpmāk - Konvencija). Konvencija definēja jēdzienu "publisks aicinājums veikt teroristisku nodarījumu”, kas saskaņā ar Konvencijas 5. panta pirmo dalu ir informācijas publiska izplatī̌sana vai citāda šìs informācijas publiskošana ar mērḳi kūdìt uz teroristisku nodarījumu veikšanu, kad šādas darbības, tieši vai netieši propagandējot teroristiskus nodarījumus, rada briesmas, ka viens vai vairāki teroristiski nodarijumi varētu tikt veikti. ${ }^{5}$ Konvencija Latvijā tika ratificēta 2008. gada 13. novembrī ar likumu "Par Eiropas Padomes Konvenciju par terorisma novēršanu".

2008. gada 12. janvārī stājās spēkā grozījumi KL, kas papildināja normatīvo regulējumu ar jaunu $88 .^{2}$ pantu "Aicinājums uz terorismu un terorisma draudi", paredzot atbildību par publisku aicinājumu uz terorismu vai draudiem īstenot terora aktu, ja ir pamats uzskatīt, ka tas var tikt veikts. ${ }^{7}$

Kārtējie grozījumi KL tika veikti 2012. gada 13. decembrī, kad $88 .{ }^{2}$ panta sankcija tika papildināta ar vārdiem "un ar probācijas uzraudzību uz laiku līdz trim gadiem vai bez tās" ", tika atrunāts arī, ka 88. ${ }^{2}$ pantā paredzētie grozījumi par papildsodu "probācijas uzraudzība” stājas spēkā 2015. gada 1 . janvārī.

\footnotetext{
Publiskais pārskats par Valsts drošỉbas dienesta darbību 2018. gadā. Rīga: Valsts drošības dienests, 2018, 28. lpp.

Ibid., 30. lpp.

Konvencija par terorisma novēršanu. Parakstīta Varšavā 16.05.2005.

Par Eiropas Padomes Konvenciju par terorisma novēršanu: LV likums. Pieņemts 13.11.2008.

Grozijumi Krimināllikumā: LV likums. Pieņemts 13.12.2007.

Grozijumi Krimināllikumā: LV likums. Pien̦emts 13.12.2012.
} 
LR IeM Informācijas centra dati liecina, ka laika posmā no 2007. gada 12. janvāra, kad stājās spēkā grozijjumi KL, kas paredzēja atbildību par aicinājumu uz terorismu un terorisma draudiem, līdz 2018. gada 23. maijam, kad KL tika iekḷauta IX ${ }^{1}$ nodaļa "Noziegumi, kas saistīti ar terorismu", KL 88. ${ }^{2}$ pants praksē tika piemērots sešas reizes (2011. gadā - 1, 2012. gadā - 1, 2014. gadā - 2, 2015. gadā - 1, 2016. gadā - 1). ${ }^{9}$ Lìdz 2018. gada beigām netika registrēts neviens kriminālprocess, kas tiktu uzsākts pēc KL IX ${ }^{1}$ nodaļā "Noziegumi, kas saistīti ar terorismu” ietvertiem pantiem.

2015. gada 22. oktobrī Rīgā Eiropas Padomes dalībvalstu pārstāvji un citas Eiropas Padomes Konvencijas par terorisma novēršanu puses parakstijušas Papildu protokolu Eiropas Padomes konvencijai par terorisma novēršanu, kas paredzēja kriminalizēt vairākus jaunus noziegumu veidus, kas saistīti ar terorismu un kas lìdz šim nebija kriminalizēti, tas ir terorisma apmācības saṇemšana, cel̦ošana uz ārvalstīm terorisma nolūkā, šādas cel̦ošanas finansēšana, organizēšana, veicināšana un citas darbïbas. ${ }^{10}$ Latvijas puse šo protokolu parakstīja 2015. gada 22. oktobrī un ratificēja 2017. gada 11. maijā. ${ }^{11}$

2017. gada 15. martā tika pien,emta Eiropas Parlamenta un Padomes Direktīva (ES) 2017/541 par terorisma apkarošanu un ar ko aizstāj Padomes Pamatlēmumu 2002/475/TI un groza Padomes Lēmumu 2005/671/TI (turpmāk - Direktīva). ${ }^{12}$ Ar šo Direktīvu dalībvalstīm ir noteikts pienākums iekḷaut Direktīvā minētās prasības savā nacionālajā normatīvajā regulējumā līdz 2018. gada 30. septembrim.

Minētie Eiropas Savienības normatīvie akti kḷuvuši par pamatojumu 2018. gada 26. aprīlī veiktajiem grozījumiem KL. ${ }^{13}$ Sākotnējā likumprojekta Nr. 984/Lp12 “ Grozījumi Krimināllikumā” (turpmāk - Likumprojekts) redakcijā KL 79. ${ }^{6}$ pantā bija paredzēta atbildība arī par īstenotā terorisma publisku noliegšanu. ${ }^{14}$ Izskatot Likumprojektu pirms pirmā lasījuma Latvijas Republikas 12. Saeimas Juridiskās komisijas sēdē, tās dalībnieks, Tiesībsarga biroja pārstāvis Juris Silčcenko vērsās pie Tieslietu ministrijas pārstāves Indras Gratkovskas ar lūgumu izskaidrot jēdziena "terorisma noliegšana” iekḷaušanas Likumprojektā iemeslus un saṇēma atbildi, ka KL ir līdzīgs pants par genocīdu, kurā ir ietverts aizliegums slavināt, attaisnot un noliegt, un ka likumprojekta autori rīkojās pēc analogijas. ${ }^{15}$ Jēdziens "noliegšana" KL 74. ${ }^{1}$ panta "Genocīda, nozieguma pret cilvēci, nozieguma pret mieru un kara nozieguma attaisnošana” izpratnē

9 Kriminālā statistika. Latvijas Republikas Iekšlietu ministrijas Informācijas centrs. Pieejams: http:// www.ic.iem.gov.lv/node/109 [aplūkots 29.04.2019.].

10 Papildu protokols Eiropas Padomes Konvencijai par terorisma novēršanu. Parakstīts Rīgā 22.10.2015.

11 Par Papildu protokolu Eiropas Padomes Konvencijai par terorisma novēršanu: LV likums. Pienememts 11.05.2017.

12 Eiropas Parlamenta un Padomes Direktīva 2017/541 par terorisma apkarošanu un ar ko aizstāj Padomes Pamatlēmumu 2002/475/TI un groza Padomes Lēmumu 2005/671/TI. Pienemta 15.03.2017.

13 Grozījumi Krimināllikumā: LV likums. Pieņemts 26.04.2018.

14 Likumprojekta "Grozījumi Krimināllikumā" anotācija. Pieejama: http://titania.saeima.lv/LIVS12/ SaeimaLIVS12.nsf/0/053367BCC6CD02DBC225815D002BA388?OpenDocument\#b [aplūkota 29.04.2019.].

15 Latvijas Republikas 12. Saeimas Juridiskās komisijas 2017. gada 6. septembra sēdes protokols Nr. 234. Pieejams: http://titania.saeima.lv/livs/saeimasnotikumi.nsf/0/6c6d026c34154258c225818700316 89f/\$FILE/PR_2017_09_06_10_00_JK.doc [aplūkots 29.04.2019.]. 
nozīmē, ka "persona kategoriski neatzīst minētos noziegumus, apgalvojot, ka tādi noziegumi vai nu vispār nav notikuši, vai ka notikušais nav atzīstams par starptautisku noziegumu, vai arī ka notikušais nav noziedzīga un sodāma rīcība"16.

Izskatot Likumprojektu pirms otrā lasījuma Juridiskās komisijas sēdē, tika atbalstīts tieslietu ministra Dzintara Rasnača un Saeimas deputāta Gunāra Kūtra priekšlikums izslēgt Likumprojektā paredzētā KL 79. ${ }^{6}$ panta pirmajā daḷā vārdu "noliegšanu" un izteikt Likumprojekta KL 79. ${ }^{6}$ panta pirmās daļas dispozīciju pašreiz spēkā esošajā redakcijā. ${ }^{17}$ Izskatot Likumprojektu pirms trešā lasījuma Latvijas Republikas 12. Saeimas Juridiskās komisijas sēdē 2018. gada 13. februārī, priekšlikumi par KL 79. ${ }^{6}$ pantu netika piedāvāti. ${ }^{18} \mathrm{KL}$ IX ${ }^{1}$ nodaļā "Noziegumi, kas saistīti ar terorismu” iekḷautais 79. ${ }^{6}$ pants stājās spēkā 2018. gada 23. maijā.

\section{Noziedzīga nodarijuma sastāva objektīvo pazīmju analize}

KL 79. ${ }^{6}$ pantā ietvertais noziedzīgais nodarījums ir klasificēts kā smags noziegums. Noziedzīga nodarījuma objekts ir "ar Krimināllikumu aizsargātas valsts, sabiedrības, cilvēku kolektīvu un atsevišķu indivīdu intereses, kuras apdraud noziedzīgs nodarījums, nodarot tām vai draudot nodarīt kaitējumu” ${ }^{19}$. Parasti krimināltiesībās izšķir vispārējo, grupas un tiešo noziedzīga nodarījuma objektu. Vispārējais noziedzīga nodarījuma objekts ir visu interešu kopums, ko aizsargā Krimināllikums. Noziedzīga nodarïjuma grupas objekts, pēc profesora Ulda Krastiņa teiktā, ir “tādas pašas vai vienāda veida un savstarpēji saistītas vairākas intereses, kuras apdraud vesela noziedzīgo nodarījumu grupa" ${ }^{20}$. Savukārt noziedzīga nodarījuma tiešais objekts ir "tās intereses, ko apdraud konkrēta veida noziedzīgs nodarījums"21.

Skaidrojot KL 88. panta, kas bija spēkā līdz 2018. gada 23. maijam, noziedzīga nodarijjuma objektu, profesors U. Krastiņš norāda, ka terorisms "apdraud Latvijas Republikas ekonomisko sistēmu un valsts vai starptautisko drošỉbu. Tajā pat laikā terorisms apdraud arī cilvēka dzīvību un veselību, mantiskās intereses, uzṇēmumu, iestāžu un organizāciju normālu darbību, vispārējo drošību un sabiedrisko kārtību." 22 Skaidrojot KL 79. ${ }^{1}$ pantu aktuālā redakcijā, profesors U. Krastiņš norāda, ka "terorisms kā sevišḳi smags noziegums apdraud Latvijas Republikas valsts drošību un ekonomisko

16 Krastiņš U., Liholaja V. Krimināllikuma komentāri. Otrā daļa (IX-XVII nodaļa). Otrais papildinātais izd. Rīga: Tiesu namu aǵentūra, 2018, 34. lpp.

17 Latvijas Republikas 12. Saeimas Juridiskās komisijas 2017. gada 8. novembra sēdes protokols Nr. 252. Pieejams: http://titania.saeima.lv/livs/saeimasnotikumi.nsf/0/8c6140349414129ac22581cc0035a494/\$FILE/PR_2017_11_08_10_00_JK.doc [aplūkots 29.04.2019.].

18 Latvijas Republikas 12. Saeimas Juridiskās komisijas 2018. gada 13. februāra sēdes protokols Nr. 273. Pieejams: http://titania.saeima.lv/livs/saeimasnotikumi.nsf/0/38320cfcc797cf9dc225822e003380da/\$FILE/PR_2018_02_13_10_00_JK.doc [aplūkots 29.04.2019.].

19 Krastiņš U., Liholaja V., Niedre A. Krimināllikuma zinātniski praktiskais komentārs. 1. Vispārīgā dal̦a. Riga: AFS, 2007, 31. lpp.

20 Krastiņš U. Noziedzīgs nodarījums. Rīga: Tiesu namu aǵentūra, 2000, 37. lpp.

21 Ibid., 39. lpp.

22 Krastiņš U., Liholaja V. Krimināllikuma komentāri. Otrā dal̦a (IX-XVII nodaḷa). Rīga: Tiesu namu aǵentūra, 2016, 71. lpp. 
sistēmu, kā arī starptautisko mieru un drošību. Terorisms var apdraudēt arī cilvēka dzīvību un veselību, mantiskās intereses, uzn̦ēmumu, iestāžu un organizāciju normālu darbību, vispārējo drošību un sabiedrisko kārtību (vairākobjektu apdraudējums).,"23

Minētais nav pretrunā arī ar ārzemju zinātnieku secinājumiem par terorisma objektīvām pazīmēm. Krievijas zinātnieks Vladimirs Davidovs (Аавыдов B. O.), atzīmējot šādu noziegumu transnacionālo raksturu, norāda, ka tiek apdraudētas dažādas ar krimināllikumu aizsargātās sabiedrisko attiecību grupas, to skaitā pilsoṇu dzīvība un veselība, sabiedriskā drošība un sabiedriskā kārtība, valsts konstitucionālās sistēmas pamati un valsts drošiba, un citas. ${ }^{24}$

Likumprojekta anotācijā, skaidrojot terorisma objektīvās pazīmes, tika atzīmēts, ka noziegumi, kas saistīi ar terorismu, bija ietverti KL X nodal̦ā "Noziegumi pret valsti”: "Minētajā nodaḷā ir ietverti tādi kaitīgi un prettiesiski nodarījumi, kas apdraud Latvijas valsts drošibu un neatkarību un kurā galvenais grupas objekts ir Latvijas valsts interešu būtiski aizskārumi. Savukārt terorismam var būt divējādas dabas - vienā gadījumā teroristu grupa vai individuāls terorists var cinnities par noteiktas valsts dalas "atbrīvošanu" vai citādu ietekmēšanu, bet otrā gadījumā - tā var būt politiska kustība, kuras darbības iziet ārpus noteiktas valsts robežām un tā mērḳis ir iedarboties uz visu pasaules sabiedrību kopumā. Lìdz ar to šobrīd pasaulē terorismam nav valstu robežas un tā mērķis ir vērsts ne tikai pret konkrētu valsti, sabiedrïbu vai starptautisku organizāciju, bet - iebiedēt un ietekmēt visas pasaules sabiedrību kopumā.".25 Lai aptvertu abus iespējamos apdraudējuma objektus, Likumprojekta autori piedāvāja noziegumus, kas saistīiti ar terorismu, ietvert atseviškāā nodạ̦ā. Viņu ieskatā tas ir nepieciešams, lai norādītu, ka persona, kas iesaistās terorisma nodarijumos, var apdraudēt ne tikai konkrētās valsts intereses, bet arī starptautisko mieru un drošību. Jēdzienu "starptautiskā drošiba” V. Davidovs skaidro kā stāvokli, kad starpvalstu attiecības tiek pasargātas no jebkāda veida pārkāpumiem, kas apdraud kopējo mieru vai tautu drošỉbu. ${ }^{26}$ Krievijas zinātnieks Maksims Andrejevs (Андреeв М. B.) norāda, ka terorisms ir mūsdienu drošỉbas pamatproblēma, kas vairāku zinātnieku pētijumos ir atzìta par globāla rakstura parādību. ${ }^{27}$

Noziedzīga nodarījuma objektīvā puse ir personas uzvedỉbas ārēja izpausme (darbība vai bezdarbỉba), kas rada vai var radīt kaitējumu "citu personu likumiskajām tiesībām un interesēm"28. Profesors U. Krastiņš, skaidrojot jēdzienu "darbība" krimināltiesiskā nozīmē, norāda, ka tã "ir personas aktīva, kaitīga un prettiesiska uzvedība, kas pauž šĩs personas apzinātu gribu un tā ir vērsta pret noziedzịga nodarijuma objektu, nodarot vai radot draudus nodarīt kaitējumu ar Krimināllikumu aizsargātām personu interesēm" 29 .

23 Krastiņš U., Liholaja V., 2018, 52. lpp.

24 Аавыдов В. О. Методика расследования транснациональной преступной деятельности экстремистского характера. Москва: Юрмитинформ, 2018, с. 23-24.

25 Likumprojekta "Grozïjumi Krimināllikumā" anotācija. Pieejama: http://titania.saeima.lv/LIVS12/ SaeimaLIVS12.nsf/0/053367BCC6CD02DBC225815D002BA388?OpenDocument\#b [aplükota 29.04.2019.]

26 Аавыдов В. О., с. 384.

27 Андреев М. В. МежАународный терроризм и межАународная безопасность нового качества. Закон и право, 2008, № 8, с. 7.

28 Krastinš̌ U., Liholaja V., Niedre A., 31.lpp.

29 Krastiņš U., 50. lpp. 
Likumprojekta anotācijā tiek skaidrots, ka KL 79. ${ }^{6}$ pantā ietvertā nozieguma "objektīvo pusi veido tas, ka persona izplata informāciju, kas satur terorisma atzinīgu novērtēšanu, cildināšanu, pozitīvas attieksmes paušanu gan attiecībā uz tādiem terora aktiem, kuru īstenošanas fakts ir konstatēts, gan uz darbībām, metodēm, paņēmieniem, kas objektīvi atbilst terorismam. [..] Minētā noziedzīgā nodarījuma objektīvā puse izpaudīsies arī kā īstenotā terorisma attaisnošana, tas ir, atzišana par pareizu, nepieciešamu, piel̦aujamu. Vienlaikus minētajām darbībām jābūt veiktām publiski, proti, persona to dara atklāti, citu personu klātbūtnē vai tādā veidā, ka citām personām tiek radīta iespēja saṇemt vai iepazìties ar šādu informāciju." ${ }^{30}$

KL 79. ${ }^{6}$ pantā ietvertais noziegums no objektīvās puses izpaužas vairākās alternatīvās darbībās: 1) kā publiskā terorisma slavināšana; 2) kā publiskā terorisma attaisnošana; 3 ) kā publisks aicinājums uz terorismu, tas ir aicinājums veikt kādu (vai vairākas) no KL 79. ${ }^{1}$ pantā uzskaitītām darbībām; 4) kā terorismu slavinošā materiāla izplatîšana; 5) kā terorismu attaisnojošā materiāla izplatīšana; 6) kā uz terorismu aicinoša satura materiāla izplatīšana vai 7) kā draudi īstenot terora aktu, ja ir pamats uzskatīt, ka tas var tikt veikts.

\section{Terorisma slavināšana un attaisnošana kā terorisma propagandas sastāvdaḷas}

2017. gada 8. novembrī, izskatot Likumprojektu pirms otrā lasījuma Latvijas Republikas 12. Saeimas Juridiskās komisijas sēdē, tās dalībnieks, Drošības policijas (no 2019. gada 1. janvāra - Valsts drošibas dienesta) pārstāvis Ints Ulmanis pilnīgi pamatoti norādijja, ka "terorisma slavināšana un attaisnošana ir viena no terorisma propagandas sastāvdal̦ām"31.

Mūsdienu latviešu valodas vārdnīcā jēdziens "propaganda” tiek skaidrots šādi: "Uzskatu, ideju, zināšanu sistemātiska izplatīšana, izskaidrošana un pamatošana nolūkā ar pārliecināšanu iegūt piekritējus." ${ }^{2}$ Skaidrojot jēdzienu "slavināšana" KL 74. ${ }^{1}$ panta "Genocīda, nozieguma pret cilvēci, nozieguma pret mieru un kara nozieguma attaisnošana” izpratnē, profesore Valentija Liholaja norāda, ka ar šo noziegumu "slavināšanu saprot tādas informācijas izplatīšanu, kas satur norādīto noziegumu atzinīgu novērtēšanu, cildināšanu, pauž personas pozitīvo attieksmi gan attiecībā uz jau īstenotajiem noziegumiem, kuru izdarīšanas fakts ir konstatēts, gan arī uz darbībām, metodēm un paņēmieniem, kas objektīvi atbilst kādam no pantā norādìtajiem starptautiskajiem noziegumiem kā tādiem"33. Savukārt jēdziens "attaisnošana” attiecībā uz minētiem noziegumiem "nozìmē

30 Likumprojekta "Grozījumi Krimināllikumā" anotācija. Pieejama: http://titania.saeima.lv/LIVS12/ SaeimaLIVS12.nsf/0/053367BCC6CD02DBC225815D002BA388?OpenDocument\#b [aplūkota 29.04.2019.]

31 Latvijas Republikas 12. Saeimas Juridiskās komisijas 2017. gada 8. novembra sēdes protokols Nr. 252. Pieejams: http://titania.saeima.lv/livs/saeimasnotikumi.nsf/0/8c6140349414129ac22581cc0035a494/\$FILE/PR_2017_11_08_10_00_JK.doc [aplūkots 29.04.2019.].

32 Mūsdienu latviešu valodas vārdnīca. Pieejama: https://tezaurs.lv/mlvv/\#/sv/propaganda [aplūkota 29.04.2019.].

33 Krastiņš U., Liholaja V., 2016, 33. lpp. 
to atzīšanu par pareizu, nepieciešamu, apstākḷu diktētu vai vismaz piel̦aujamu rīcību, atsaucoties uz informāciju, kas neatbilst patiesībai, manipulējot ar faktiem utt." 34

Atsaucoties uz sava empīiskā pētījuma rezultātiem, V. Davidovs, izškirir trīs veidus, kādos tiek attaisnota teroristu lietota vardarbỉba. Pirmais veids izpaužas kā paziṇojumi par to, ka nelielām lokālajām grupām, kas ir novājinātas, jo cieš no valsts varas iestāžu, tiesībaizsardzības iestāžu un speciālo dienestu īstenotām represijām, vardarbības izmantošana bija vienīgā iespējamā atbildes reakcija uz šīm represijām. Otrais attaisnošanas veids izpaužas kā valsts varas iestāžu, tiesībaizsardzības iestāžu un speciālo dienestu demonizācija un delegitimizācija, kas tiek īstenota vienlaikus ar teroristu slavināšanu, viṇu pozicionēšanu kā brīvības cīnītāju, kas lieto vardarbỉbu, cīnoties par cilvēktiesību ievērošanu un nacionālās (religiskās) brīvības aizsardzību. Trešais attaisnošanas veids izpaužas kā pazin,ojumi par to, ka teroristi rīkojās, izmantojot nevardarbīgās metodes. ${ }^{35}$

KL 79. ${ }^{6}$ pantā minētās darbības var izpausties mutvārdos vai rakstveidā. Šāda veida informāciju var izplatīt, izmantojot audio un videofailus, kā arī fotoattēlus, zīmējumus, atribūtus un simbolus. Tiesu prakse liecina, ka biežāk informācija, kas satur aicinājumus uz terorismu, terorismu attaisnojošā vai slavinājušā, tiek izplatīta, izmantojot automatizētu datu apstrādes sistēmu. Interneta izmantošana šãda veida noziedzīgos nodarījumos ir raksturīga kā Eiropas Savienības, tā arī citām pasaules valstīm. Piemēram, pēc Krievijas Federācijā veiktajiem pētījumiem, izplatot šāda satura informāciju, internets tika izmantots no $79,1 \%{ }^{36} \mathrm{li} \mathrm{dz}$ pat $92 \%$ gadījumu. ${ }^{37}$ Krievijas zinātnieks V. Davidovs norāda, ka tas ir saistīts ar vairākiem apstākḷiem, kas šḳiet pievilcīgi transnacionālo teroristisko grupējumu dalībniekiem. ${ }^{38}$ Viņš nosauc šãdus apstākḷus: interneta pieejamība, vāja cenzūra (vai tās neesamība), liels potenciālo lietotāju skaits, plašas geoogrāfiskās teritorijas aptveršana, lietotāju anonimitāte, informācijas izplatīšanas ātrums un zemas izmaksas.

Profesore Tatjana Pinkeviča (Пинкевич T. В.) un Jevgen,ija Černiha (Черных Е. E.) pamatoti norāda, ka visām terorisma izpausmēm ir raksturīgs publiskums, atklātums un propagandas raksturs. ${ }^{39}$ Jo lielāku sabiedrisko rezonansi izraisa terorisma akts, jo lielāka tā ietekme uz iedzìvotājiem ar nolūku "iebiedēt iedzīvotājus vai piespiest valsti, tās institūcijas vai starptautiskas organizācijas izdarīt kādu darbību vai atturēties no tās, vai kaitēt valsts, tās iedzīvotāju vai starptautiskas organizācijas interesēm" ${ }^{40}$. Krievijas zinātnieces T. Pinkeviča un J. Černiha pamatoti secina, ka psihologiskā ietekme uz personām ir terorisma galamērḳis, nevis šis darbības blakusefekts.

\footnotetext{
Ibid., 33.-34. lpp.

Аавыдов В. О., с. 81.

Ibid., c. 60 .

37 Иванцов С. В., Узембаева Г. И. Противодействие преступлениям экстремистской направменности, совершаемым с использованием средств массовой информации или информационнотелекоммуникационных сетей: уголовно-правовые и криминологические аспекты. Москва: Юрмитинформ, 2018, с. 92.

38 Аавыдов В. О., с. 80.

39 Пинкевич Т. В., Черных Е. Е. Публичные призывы к осуществлению террористической Аеятемьности или публичное оправдание терроризма: проблемы квалификации. Юридическая наука и практика: Вестник НижегороАской акаАемии МВА России, 2014, № 3, с. 141.

40 Krimināllikuma 79.1 pants: LV likums. Pieņemts 17.06.1998. [07.11.2018. red.].
} 
Latvijas Republikas Satversmes tiesas tiesnesis Artūrs Kučs, atsaucoties uz ANO Rasu diskriminācijas izskaušanas komitejas praksi, norāda, ka "objektīvās puses konstatēšanai nepieciešama vismaz minimāla personas izteikumu publiskuma pakāpe"41 un secina, ka divu personu izteikumi, kas neskar pārējo sabiedrību, nebūs uzskatāmi par publiskiem. Līdzīgās domās ir Krievijas zinātnieks Zaurbeks Šibzuhovs (Шибзухов 3. A.), kurš, raksturojot Krievijas Federācijas Kriminālkodeksa $205 .^{2}$ pantu, kas pēc satura ir līdzīgs KL 79. ${ }^{6}$ pantam, norāda, ka šādas darbības vienmēr būs vērstas uz sabiedrību, t. i., uz informācijas nodošanu nenoteiktam un pēc iespējas plašākam cilvēku lokam. ${ }^{42}$ Kaut arī lielākā daḷa zinātnieku (rakstā minētie A. Kučs, S. Ivancovs, G. Uzembajeva, A. Tarbagajevs, G. Moskalevs, T. Pinkeviča, J. Černiha, Z. Šibzuhovs) atbalsta nostāju, ka par publiskiem tiek atzīti izteicieni un aicinājumi, kas izteikti divām vai vairāk personām, tomēr kaimin,valsts likumpiemērošanas praksē ir arī atškirīgie piemēri.

Profesors Aleksejs Tarbagajevs (Тарбагаев A. H.) un Georgijs Moskalevs (Mocкaлев Г. А.), atsaucoties uz Krievijas Federācijas Augstākās tiesas 2014. gada 27. marta lēmumu, apraksta kādu gadijumu, kad persona tika sodīta ar brīvības atṇemšanu uz diviem gadiem par publiskiem aicinājumiem uz terorismu un terorisma publisku attaisnošanu. ${ }^{43}$ No lietas materiāliem izriet, ka minētā persona šos aicinājumus bija izteikusi divām personām, bet katrai atseviškłi, citā laikā un vietā. Minētais neietekmēja Krievijas Federācijas Augstākās tiesas lēmumu, kas atstāja negrozītu Čečenijas Republikas Augstākās tiesas 2014. gada 27. janvāra spriedumu un noraidīja advokāta apelācijas sūdzību. Raksta autora ieskatā, izdarītajā nodarījumā nav noziedzīga nodarījuma sastāva, jo terorisma publiskā slavināšana vai attaisnošana vai publiskie aicinājumi uz terorismu, kā noziedzīgais nodarījums, no objektīvās puses paredz šo darbību publisko izpausmi. Vienlaikus autors norāda, ka minētā gadījumā ir saskatāmas cita noziedzīgā nodarījuma - personas vervēšanas terorismam - pazīmes.

Publiskā izpausme ir nepieciešama, arī lai konstatētu noziedzīga nodarījuma sastāvu lietās par aicinājumu uz terorismu.

\section{Publiskais aicinājums uz terorismu}

Profesors U. Krastiņš atzīst: "Aicinājums ir tāda fiziskās vai psihiskās iedarbības forma uz cilvēku apziņu, gribu, uzvedību, kad, iedarbojoties uz vin,u, tam rodas vai var rasties vēlme veikt noteikta veida mērḳtiecīgu darbību, šajā gadījumā terorismu." ${ }^{44}$ Profesors U. Krastiņš atzīmē, ka aicinājums uz terorismu vērsts uz nekonkretizētu personu loku. Šādu nostāju atbalsta vairāki zinātnieki (piemēram, A. Tarbagajevs,

${ }^{41}$ Kučs A. Tiesu prakse krimināllietās par nacionālā, etniskā un rasu naida izraisīšanu. Rīga, 2012, 31. lpp. Pieejams: http://at.gov.lv/files/uploads/files/docs/petijumi/Apkopojums naida kurinasana.doc [aplūkots 29.04.2019.].

42 Шибзухов 3. А. Публичные призывы к осуществлению террористической деятельности или публичное оправдание терроризма. Москва: Юрлитинформ, 2014, с. 18-19.

43 Тарбагаев А. Н., Москалев Г. А. Публичные призывы к осуществлению террористической Аеятельности (ст. 205.2 УК РФ): проблемы уголовно-правовой регламентации и квалификации. Вестник Санкт-Петербургского университета. Серия 14. Право, 2016, № 2, с. 33.

${ }^{44}$ Krastiņš U., Liholaja V., 2018, 64. lpp. 
G. Moskalevs, T. Pinkeviča, J. Černiha u. c.). Ir arī citāds viedoklis. Krievijas zinātnieks Vitālijs Aḷehins (Алехин В. П.) norāda, ka aicinājumam uz terorismu jābūt vērstam uz konkrēto darbību. ${ }^{45}$ Viņa ieskatā, nevar aicināt veikt teroristisko darbību vispār, nenosakot konkrēto uzbrukuma objektu un darbības veidu.

Vērtējot publiskos aicinājumus, A. Tarbagajevs un G. Moskalevs pauž viedokli, ka aicinājumu izplatītājiem nav svarīgas aicinājumu saṇēmēju individuālās iezīmes, un tieši tādēl viṇi vēršas ar aicinājumiem, uzrunājot personu grupu publiskajās vietās, sapulcēs, kā arī masveidā izsūtot elektroniskās vēstules. ${ }^{46}$ Papildinot teikto, raksta autors norāda, ka šeit jānošḳir individuālās iezīmes no piederības kādai nacionālai vai sociālai grupai. Parasti aicinājuma izplatītājam ir sava mērķauditorija. Piemēram, gadījumos, kad ar aicinājumu veikt terora aktu persona vēršas pie kādas konkrētas nacionālās (religiskās) grupas pārstāvjiem.

Parasti aicinājums tiek izteikts pavēles izteiksmē (imperatīvā). Darbības vārds pavēles izteiksmē tiek lietots, ja ar to tiek izteikta pavēle, pamudinājums, aicinājums, lūgums. Krievijas zinātnieki A. Tarbagajevs un G. Moskalevs uzskata, ka aicinājumam vienmēr jābūt izteiktam tikai pavēles izteiksmē. ${ }^{47}$ Tomēr raksta autors tam nepiekrìt, jo krimināltiesību zinātnieki norāda, ka dažreiz aicinājumi tiek izteikti aizplīvurotā veidā, izmantojot darbības vārdus vēlējuma izteiksmēe, ${ }^{48}$ vai izmantojot izteicienus: "būtu labi, ja", "es vēlētos, lai" u. c. ${ }^{49}$ Darbības vārds vēlējuma izteiksmē tiek lietots, ja tiek norādīts uz vēlamu darbību, kas noteiktos apstākḷos var būt iespējama vai neiespējama. Dažreiz aicinājumi tiek izteikti aizplīvurotā veidā, izmantojot alegorijas (notikumi un parādības tiek atspoguḷotas simboliski, nevis stāstoši), metaforas (viens no mākslinieciskās izteiksmes līdzekḷiem, kas bieži tiek izmantots dzejā), retoriskus jautājumus (jautājumus, uz kuriem nav nepieciešama atbilde), vai citus mākslinieciskās izteiksmes paṇēmienus. ${ }^{50}$

Profesors U. Krastinšs norāda, ka noziegums visos tā veidos ir "pabeigts ar noziedzīgo darbību izdarīšanu, jo kaitīgās sekas analizējamā panta dispozīcijā netiek apzīmētas, tas ir, nav tajā iekḷautas" ${ }^{\text {1. }}$. U. Krastinca pirms diviem gadiem piedāvātais skaidrojums bija precīzāks: "Neatkarīgi no tā, vai terora akts pēc tam ticis izdarìts vai nav." ${ }^{2}$ Abi skaidrojumi pārliecinoši norāda uz to, ka KL 79. ${ }^{6}$ pantā ietvertam noziegumam ir formālais sastāvs.

45 Алехин В. П. Соучастие в террористической деятельности. Москва: Юрлитинформ, 2009, с. 109.

46 Тарбагаев А. Н., Москамев Г. А. Публичные призывы к осуществлению террористической Аеятельности (ст. 205.2 УК РФ): проблемы уголовно-правовой регламентации и квалификации. Вестник Санкт-Петербургского университета. Серия 14. Право, 2016, № 2, с. 33.

47 Ibid., c. 30 .

48 Шибзухов 3. А. Публичные призывы к осуществлению террористической деятельности или публичное оправдание терроризма. Москва: Юрмитинформ, 2014, с. 69-72.

49 Шуйский А. С. Ответственность за публичные призывы к осуществлению террористической Аеятельности или публичное оправдание терроризма. В kн.: Актуальные проблемы уголовного и уголовно-исправительного права: сборник научных статей. Москва: Академия Генеральной прокуратуры РФ, 2010, с. 68-69.

50 Trel̦ Ē. Teksta juridiskās ekspertīzes īpašības lietās par naida izraisīšanu. No: Rīgas Stradina universitātes Juridiskās fakultātes elektroniskais juridisko zinātnisko rakstu žurnāls Socrates 2016, Nr. 1, 49. lpp.

51 Krastiņš U., Liholaja V., 2018, 66. lpp.

52 Krastinš̌ U., Liholaja V., 2016, 77. lpp. 


\section{Terorismu slavinošā, attaisnojošā vai uz terorismu aicinošā satura materiāla izplatī̌sana}

Noziedzīgais nodarījums, kas izpaužas uz terorismu aicinoša satura materiāla izplatīšanā, par pabeigtu būs atzīstams no brīža, kad tiks uzsākta šāda satura materiāla izplatǐšana. Gadījums, kad uz terorismu aicinoša satura materiāli ir sagatavoti, bet nav izplatīti, jāvērtē kā sagatavošanos noziegumam (KL 15. panta otrā un trešā daļa). Krievijas zinātnieki Sergejs Ivancovs (Иванцов С. В.) un Guḷfija Uzembajeva (Узембаева Г. И.) nosauc vairākus piemērus, kad šāds noziegums uzskatāms par pabeigtu. ${ }^{53}$ Gadijumos, kad izmantoti masu saziṇas līdzekḷi, tas ir: drukāto laikrakstu un žurnālu pārdošana vai bezmaksas izplatīšana, audio un videoierakstu pārdošana vai bezmaksas izplatīšana, televīzijas pārraides vai radiopārraides sākums, filmas vai kinodokumentu demonstrācijas sākums, materiālu izvietošana internetā u. c.

Latvijas Republikas Satversmes tiesas tiesnesis A. Kučs norāda, ka personai nav obligāti jābūt izplatītā materiāla autoram, jo "noziedzīgā nodarījuma objektīvā puse var izpausties, arī izplatot citu personu izteikumus" ${ }^{54}$. Krievijas zinātnieku vidū pastāv domstarpības par personu lomu sadali kopīgi izdarìtajā nodarījumā lietās par terorismu slavinošā, attaisnojošā vai uz terorismu aicinošā satura materiāla izplatǐšanu. A. Tarbagajevs un G. Moskalevs uzskata, ka pie atbildības jāsauc tikai šāda materiāla izplatītājs. ${ }^{55}$ Viṇi norāda, ka gadījumā, kad informācijas autors un informācijas izplatītājs ir dažādas personas, izmeklētājiem var rasties grūtības noziedzīgā nodarījuma kvalifikācijā. Daži zinātnieki (P. Agapovs, Z. Šibzuhovs) uzskata, ka šajā situācijā abas personas būs līdzizdarītāji, ${ }^{56}$ citi autori (A. Tarbagajevs, G. Moskalevs) norāda, ka uz terorismu vērstās informācijas autors būs līdzdalībnieks - atbalstītājs. Argumentējot savu nostāju, Z. Šibzuhovs norāda, ka šajā gadījumā teksta sagatavošana ir noziedzīga nodarījuma objektīvās puses pirmais posms, bet izplatīšana - otrais. ${ }^{57}$

Gadījumos, kad noziedzīgā nodarījumā ir iesaistītas vairākas personas, izmeklētājam var rasties problēmas arī ar subjektīvās puses pierādī̌̌anu. Noziedzīga nodarījuma subjektīvā puse ir personas iekšējā attieksme pret ārējā pasaulē objektīvi notiekošo. ${ }^{58}$ Krimināltiesību teorijā tiek izšḳirtas šādas noziedzīga nodarījuma subjektīvās puses pa-

53 Иванцов С. В., Узембаева Г. И. Противодействие преступлениям экстремистской направленности, совершаемым с использованием среАств массовой информации или информационнотелекоммуникационных сетей: уголовно-правовые и криминологические аспекты. Москва: Юрмитинформ, 2018, с. 38.

54 Kučs A. Tiesu prakse krimināllietās par nacionālā, etniskā un rasu naida izraisīšanu. Rīga, 2012, 31. lpp. Pieejams: http://at.gov.lv/files/uploads/files/docs/petijumi/Apkopojums naida kurinasana.doc [aplūkots 29.04.2019.]

55 Тарбагаев А. Н., Москамев Г. А. Публичные призывы к осуществлению террористической Аеятельности (ст. 205.2 УК РФ): проблемы уголовно-правовой регламентации и квалификации. Вестник Санкт-Петербургского университета. Серия 14. Право, 2016, № 2, с. 28.

56 Агапов П. В. Публичные призывы к осуществлению террористической деятельности или публичное оправдание терроризма: анализ законодательной новации. Уголовное право, 2007, № 1, с. 6.

57 Шибзухов 3. А. Проблемы квалификации публичных призывов к осуществлению террористической Аеятельности или публичного оправАания терроризма, совершенных в соучастии. Общество и право, 2011, № 2, с. 184-187.

58 Krastinš U., 88. lpp. 
zīmes: vaina nodoma vai neuzmanības formā, motīvs un mērḳis (nolūks). KL 8. panta pirmā daḷa paredz, ka par vainīgu noziedzīgā nodarījumā atzīstama tikai persona, kas to izdarījusi ar nodomu (tî̌i) vai aiz neuzmanības. Procesa virzītājam, lai noskaidrotu noziedzīgo nodarījumu izdarījušās personas vainas formu, jākonstatē šīs personas psihiskā attieksme pret noziedzīgā nodarījuma objektīvajām pazīmēm. Tātad izmeklētājam jāpierāda, ka informācijas autors apzinājās, ka informācija būs izplatīta publiski, bet par izplatītāju jāpierāda, ka vin,š apzinājās, ka viṇa izplatītais materiāls satur terorismu slavinošo, attaisnojošo vai uz terorismu aicinošo informāciju.

Profesors U. Krastiņš norāda, ka motīvs un mērkisis ietekmē nodoma rašanos, tā virzību uz mērḳi un nodoma īstenošanos. ${ }^{59}$ Motīvs tiek definēts kā iekšējais pamudinājums, dziṇa, tieksme, kas virza vainīgā gribu uz noziedzīga nodarījuma izdarīšanu. Savukārt mērḳis ir iecerētais rezultāts, ko persona, izdarot noziedzīgu nodarījumu, vēlas sasniegt. KL 79. ${ }^{6}$ pantā minētās darbības motīvs ir pamudināt sabiedrības pārstāvjus veikt teroristiskos aktus un (vai) citas KL 79. ${ }^{1}$ pantā ietvertās darbības. Kā pamatoti norāda Krievijas zinātnieks Jurijs Pudovočkins (Пудовочкин Ю. E.), tieši šīs darbības mērķtiecība atšķiir aicinājumu uz terorismu no personiskā viedokḷa paušanas sarunās par valstiskiem, politiskiem un nacionāliem jautājumiem gimenes vai draugu lokā. ${ }^{60}$

Pamatojoties uz veikto analīzi, VDD pārstāvji secina: "Viens no būtiskiem riskiem, kas skar ikvienu valsti - arī Latviju -, ir internetā brīvi pieejamie teroristisko organizāciju propagandas materiāli. Propaganda VDD vērtējumā ir viens no noteicošajiem faktoriem, kas šobrīd ietekmē Eiropā dzīvojošo personu radikalizēšanos, kā arī iesaistīšanos teroristiskās darbībās." ${ }^{61}$ VDD pārstāvji prognozē, ka "ṇemot vērā, ka joprojām pasaulē ir atškịīga attieksme pret nepieciešamību nodrošināt interneta vides stingrāku regulēšanu, paredzams, ka arī turpmāk teroristu propaganda internetā iedvesmos radikāli tendētas personas iesaistīties teroristiskās darbībās" ${ }^{62}$. Minētais l̦auj secināt, ka arī turpmāk aktualitāti nezaudēs jautājums par terorisma publisku slavināšanu vai attaisnošanu, kā arī par publisku aicinājumu uz terorismu.

\section{Secinājumi}

1. KL IX ${ }^{1}$ nodaļas "Noziegumi, kas saistīti ar terorismu” galvenais grupas objekts ir valsts un starptautiskā drošība. Terorisms apdraud arī personu dzivību un veselỉbu, mantiskās intereses, uzṇēmumu, iestāžu un organizāciju normālo darbību, vispārējo drošību un sabiedrisko kārtību, kā arī citas svarīgās intereses.

2. KL 79. ${ }^{6}$ pantā ietvertais noziegums no objektīvās puses izpaužas vairākās alternatīvās darbībās: 1) kā publiskā terorisma slavināšana; 2) kā publiskā terorisma attaisnošana; 3 ) kā publisks aicinājums uz terorismu, tas ir aicinājums veikt kādu

59 Ibid., 108.-109.1pp.

60 Пудовочкин Ю. Е. Преступления против безопасности государства. Москва: Юрлитинформ, 2009 , с. 75.

61 Publiskais pārskats par Valsts drošỉbas dienesta darbību 2018. gadā. Rīga: Valsts drošỉbas dienests, 2018, 33. lpp.

62 Ibid. 
(vai vairākas) no KL 79. ${ }^{1}$ pantā uzskaitītām darbībām; 4) kā terorismu slavinošā materiāla izplatīšana; 5) kā terorismu attaisnojošā materiāla izplatî̌šana; 6) kā uz terorismu aicinoša satura materiāla izplatī̌šana vai 7) kā draudi isstenot terora aktu, ja ir pamats uzskatìt, ka tas var tikt veikts.

3. Terorisma publiskā slavināšana, terorisma publiskā attaisnošana un publiskie aicinājumi uz terorismu kā noziedzīgais nodarījums no objektīvās puses paredz šo darbỉbu publisko izpausmi. Terorisma slavināšana, attaisnošana vai aicinājums uz terorismu būs publisks gadījumā, kad tiks izteikts divām vai vairāk personām. Izteikumi, kas izteikti tikai divu personu starpā un neskar pārējo sabiedrību, nebūs uzskatāmi par publiskiem.

4. KL 79. ${ }^{6}$ pantā paredzētā noziedzīgā nodarījuma subjekts ir vispārīgais - fiziska pieskaitāma (KL 13. pants) persona, kas sasniegusi četrpadsmit gadu vecumu (KL 11. pants).

5. KL 79. ${ }^{6}$ pantā ietvertā noziedzīga nodarījuma subjektīvā puse izpaužas tieša nodoma veidā. Persona apzinās savu darbību kaitīgumu un vēlas izteikt aicinājumu, attaisnot vai slavināt terorismu, izplatīt terorismu slavinošos, attaisnojošos vai uz terorismu aicinošos materiālus. KL 79. ${ }^{6}$ pantā minētās darbības motîvs ir pamudināt sabiedrības pārstāvjus veikt teroristiskos aktus un (vai) citas KL 79. ${ }^{1}$ pantā ietvertās darbības.

6. KL 79. ${ }^{6}$ pantā ietvertam noziegumam ir formālais sastāvs.

7. KL K9. ${ }^{6}$ pantā minētās darbības var izpausties mutvārdos vai rakstveidā. Šãda veida informāciju var izplatìt, izmantojot audio un videofailus, kā arī fotoattēlus, zìmējumus, atribūtus un simbolus.

8. Publiskie aicinājumi uz terorismu tiek izteikti pavēles izteiksmē, tã vēlējuma izteiksmē. Dažreiz aicinājumi tiek izteikti aizplīvurotā veidā, izmantojot izteicienus: "būtu labi, ja", "es vēlētos, lai" u. c., kā arī izmantojot alegorijas, metaforas un citus mākslinieciskās izteiksmes pañēmienus.

9. Terorisma propagandas galvenais izplatî̌sanas avots ir internets.

\section{BIBLIOGRĀFIJA}

1. Krastiņš U., Liholaja V. Krimināllikuma komentāri. Otrā daļa (IX-XVII nodaḷa). Otrais papildinātais izd. Rìga: Tiesu namu aǵentūra, 2018.

2. Krastiņš U., Liholaja V. Krimināllikuma komentāri. Otrā daḷa (IX-XVII nodaḷa). Rīga: Tiesu namu aǵentūra, 2016.

3. Krastiņ̌̌ U., Liholaja V., Niedre A. Krimināllikuma zinātniski praktiskais komentārs. 1. Vispārīgā daļa. Rìga: AFS, 2007.

4. Krastiņš U. Noziedzīgs nodarījums. Rīga: Tiesu namu aǵentūra, 2000.

5. Kučs A. Tiesu prakse krimināllietās par nacionālā, etniskā un rasu naida izraisiš̌anu. Pētījums. Rīga, 2012, 51. lpp. Pieejams: http://at.gov.lv/files/uploads/files/docs/petijumi/Apkopojums naida kurinasana.doc [aplūkots 29.04.2019.].

6. Publiskais pārskats par Valsts drošības dienesta darbību 2018. gadā. Rīga: Valsts drošības dienests, 2018. 
7. Trel̦ Ē. Teksta juridiskās ekspertīzes īpašỉbas lietās par naida izraisīšanu. No: Rīgas Stradina universitātes Juridiskās fakultātes elektroniskais juridisko zinātnisko rakstu žurnāls Socrates, 2016, Nr. 1, 46.-56.lpp.

8. Агапов П. В. Публичные призывы к осуществлению террористической Аеятельности или публичное оправдание терроризма: анализ законодательной новации. Уголовное право, 2007, № 1, c. 4-6.

9. Алехин В. П. Соучастие в террористической деятельности. Москва: Юрлитинформ, 2009.

10. Андреев М. В. МежАународный терроризм и международная безопасность нового качества. Закон и право, 2008, № 8, с. 7-9.

11. Аавыдов В. О. Методика расследования транснациональной преступной деятельности экстремистского характера. Москва: Юрмитинформ, 2018.

12. Иванцов С. В., Узембаева Г. И. Противодействие преступлениям экстремистской направленности, совершаемым с использованием среАств массовой информации или информационно-телекоммуникационных сетей: уголовно-правовые и криминологические аспекты. Москва: Юрлитинформ, 2018.

13. Пинкевич Т. В., Черных Е. Е. Публичные призывы к осуществлению террористической Аеятельности ими публичное оправдание терроризма: проблемы квалификации. Юридическая наука и практика: Вестник НижегороАской акаАемии МВА России, 2014, № 3, с. 141-144.

14. Пудовочкин Ю. Е. Преступления против безопасности госуАарства. Москва: Юрлитинформ, 2009.

15. Тарбагаев А. Н., Москалев Г. А. Публичные призывы к осуществлению террористической Аеятельности (ст. 205.2 УК РФ): проблемы уголовно-правовой регламентации и квалификации. Вестник Санкт-Петербургского университета. Серия 14. Право, 2016, № 2, с. 28-39.

16. Шибзухов 3. А. Публичные призывы к осуществлению террористической Аеятельности ими публичное оправдание терроризма. Москва: Юрмитинформ, 2014.

17. Шуйский А. С. Ответственность за публичные призывы к осуществлению террористической деятельности или публичное оправАание терроризма. В kн.: Актуальные проблемы уголовного и уголовно-исправительного права: сборник научных статей. Москва: Академия Генеральной прокуратуры РФ, 2010, с. 68-69.

\section{Likumi un normativie akti}

18. Eiropas Parlamenta un Padomes Direktīva 2017/541 par terorisma apkarošanu un ar ko aizstāj Padomes Pamatlēmumu 2002/475/TI un groza Padomes Lēmumu 2005/671/TI. Pieñemta 15.03.2017.

19. Likumprojekta “Grozījumi Krimināllikumā” anotācija. Pieejama: http://titania.saeima. lv/LIVS12/SaeimaLIVS12.nsf/0/053367BCC6CD02DBC225815D002BA388?OpenDocument\#b [aplūkota 29.04.2019.]

20. Grozījumi Krimināllikumā: LV likums. Pieṇemts 26.04.2018.

21. Grozijumi Krimināllikumā: LV likums. Pieņemts 13.12.2012.

22. Grozījumi Krimināllikumā: LV likums. Pieṇemts 13.12.2007.

23. Konvencija par terorisma novēršanu. Parakstīta Varšavā 16.05.2005.

24. Kriminālā statistika. Latvijas Republikas Iekšlietu ministrijas Informācijas centrs. Pieejams: http://www.ic.iem.gov.lv/node/109 [aplūkots 29.04.2019.].

25. Krimināllikums: LV likums. Pieņemts 17.06.1998. [07.11.2018. red.]. 
26. Latvijas Republikas 12. Saeimas Juridiskās komisijas 2018. gada 13. februāra sēdes protokols Nr. 273. Pieejams: http://titania.saeima.lv/livs/saeimasnotikumi.nsf/0/38320cfcc797cf9dc225822e003380da/\$FILE/PR_2018_02_13_10_00_JK.doc [aplūkots 29.04.2019.].

27. Latvijas Republikas 12. Saeimas Juridiskās komisijas 2017. gada 8. novembra sēdes protokols Nr. 252. Pieejams: http://titania.saeima.lv/livs/saeimasnotikumi.nsf/0/8c6140349414129ac22581cc0035a494/\$FILE/PR_2017_11_08_10_00_JK.doc [aplūkots 29.04.2019.].

28. Latvijas Republikas 12. Saeimas Juridiskās komisijas 2017. gada 6. septembra sēdes protokols Nr.234. Pieejams: http://titania.saeima.lv/livs/saeimasnotikumi.nsf/0/6c6d026c34154258c22581870031689f/\$FILE/PR_2017_09_06_10_00_JK.doc [aplūkots 29.04.2019.].

29. Papildu protokols Eiropas Padomes Konvencijai par terorisma novēršanu. Parakstīts Rīgā 22.10.2015.

30. Par Eiropas Padomes Konvenciju par terorisma novēršanu: LV likums. Pieņemts 13.11.2008.

31. Par Papildu protokolu Eiropas Padomes Konvencijai par terorisma novēršanu: LV likums. Pieņemts 11.05.2017.

\section{Interneta resursi}

32. Mūsdienu latviešu valodas vārdnīca. Pieejama: https://tezaurs.lv/mlvv/ [aplūkota 29.04.2019.]. 